\title{
Methodological approach to study the genomic profile of the human breast
}

\author{
GABRIELA A. BALOGH ${ }^{1}$, REBECCA HEULINGS ${ }^{1}$, DANIEL MAILO ${ }^{1}$, RICHARD WANG ${ }^{1}$, \\ YUE-SHENG LI ${ }^{2}$, RANDY HARDY ${ }^{2}$ and JOSE RUSSO ${ }^{1,3}$ \\ ${ }^{1}$ Breast Cancer Research Laboratory and ${ }^{2}$ DNA Microarray Facility, Fox Chase Cancer Center, Philadelphia, PA, USA
}

Received February 20, 2007; Accepted April 23, 2007

\begin{abstract}
One of the key end-points for understanding the molecular basis of the breast in its normal and cancer status is the quantitation of gene expression in specific cell populations. Microdissection techniques allow extraction of morphologically distinct cells for molecular analysis. The objective of this study was to determine the optimal RNA isolation and amplification to perform genomic expression analysis using the microarray technique from normal breast paraffin-embedded tissue samples using laser capture microdissection (LCM). We isolated epithelial and interlobular stroma cells from normal breast tissue and the total RNA was amplified using a PCR methodology developed by us, and in parallel the same starting material was used for amplification using the linear methodology. After two rounds of RNA amplification, we checked the quality of each amplified RNA and carried out the hybridization with cDNA glass-microarrays employing 15,000 genes for each replicate. In conclusion, we have successfully demonstrated that our PCR methodology is accurate and precise and give us a higher yield of amplified RNA from small number of cells obtained from LCM compared with the typical linear amplification methodology.
\end{abstract}

\section{Introduction}

The breast is a bilateral organ that in the female undergoes dramatic changes in size, shape, and function in association with infantile growth, puberty, pregnancy, lactation, and post-menopausal regression (1-4). The fact that the breast is the source of the most frequently diagnosed malignancy in the female population $(5,6)$ requires to fully understand

Correspondence to: Dr Jose Russo, Breast Cancer Research Laboratory, Fox Chase Cancer Center, 333 Cottman Ave., Philadelphia, PA 19111, USA

E-mail: j_russo@fccc.edu

Key words: laser capture microdissection, breast, microarray, PCR amplification, linear amplification how the various phases of development are influenced by reproductive events, because they will ultimately determine the risk of developing breast cancer $(3,4,7)$. The breast tissue of normally cycling non-pregnant adult women contains two identifiable types of lobules, the lobule type 1 (Lob 1) and the more developed lobule type 2 (Lob 2). During pregnancy and lactation two new lobular structure emerge the lobule type 3 (Lob 3) and lobule type 4 (Lob 4) respectively (3). Breast development occurs through a process of ductal elongation, branching and sprouting of ductules or acini, a process that requires extensive cell proliferation and penetration of the ductal epithelium into the stroma (3). Both the intralobular and the interlobular stroma are affected simultaneously during development, pregnancy, lactation, and involution $(8,9)$. These processes occur, in turn, in a synchronous manner in response to specific hormonal and growth factor stimuli $(3,8-10)$. Based on these biological considerations is of utmost importance to determine efficient methods to isolate and amplify RNA from small samples and to determine that this procedure can be applied to laser captured epithelia and the stroma of the breast. This in turn will allow us to understand the molecular process imprinted in the human breast during development, parity or hormonal exposure.

In the present work, we used laser capture microdissection (LCM) to selectively obtain pure cell populations from the breast epithelial ductal structures and from the stroma for RNA isolation (11-14). The technique allows the precise extraction of pure cell populations from fixed tissue sections by adhering the selected cells to a thermoplastic film by using an infrared laser pulse (15). When the film is lifted, the 'captured' cells can be transferred directly into a digestion buffer for extraction of nucleic acids for subsequent analysis (16). Several studies have shown the genomic expression from isolated tumor breast cells using LCM (17-23), however very few publications (20-24) show the successful gene expression study using microarrays technologies from laser captured breast epithelial cells from paraffin-embeddednormal breast tissue. Another objective of the present work is to compare two different methods of RNA amplification, the linear one already described in the literature $(25,26)$ and a PCR based method developed in our laboratory. Altogether, the final objective is the optimization of the cells obtained by LCM from ethanol fixed and paraffin-embedded breast tissue for obtaining good quality and high yield of RNA to perform genomic studies using the cDNA microarray. 
1
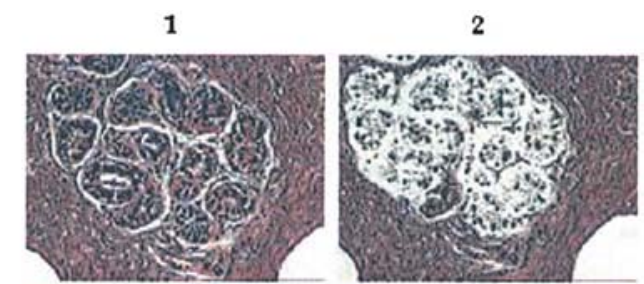

B

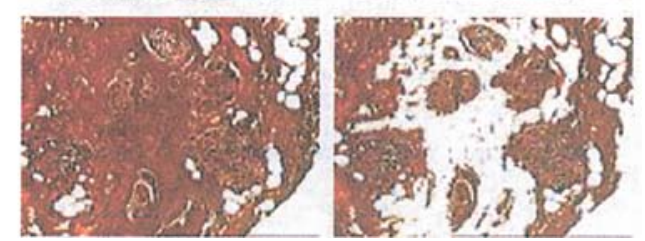

Figure 1. Normal breast epithelial and interlobular stroma cells dissected by LCM. Pure breast epithelial cells from lobule type I were captured, separating them from the surrounding cells of the stroma. (A) Lobule type 1 from normal breast, section of $5-\mu \mathrm{m}$ ethanol-fixed paraffin-embedded, before (1) and after LCM (2). (B) Interlobular stroma cells before (1) and after the LCM (2).

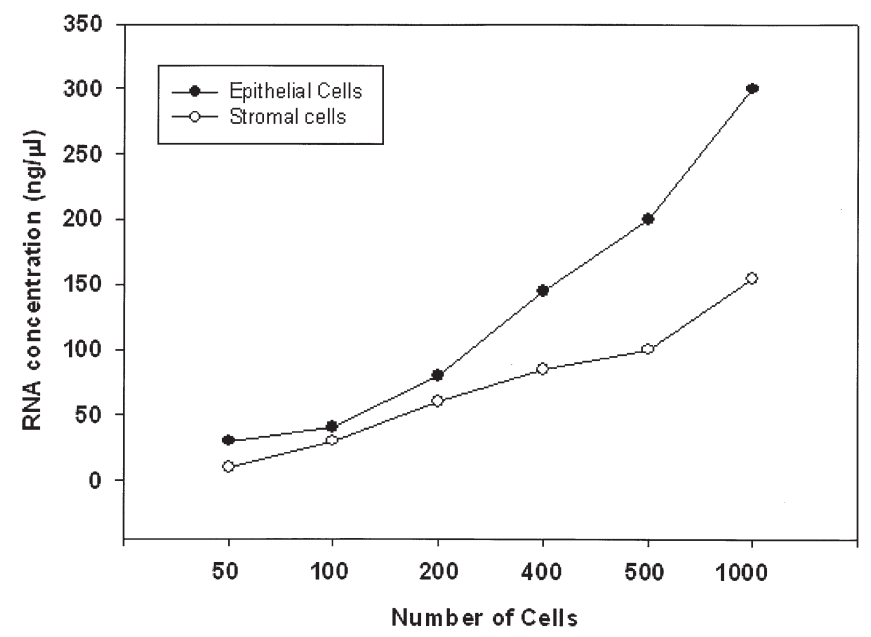

Figure 2. Total RNA concentration versus number of epithelial and stroma cells captured by LCM from normal breast tissue.

\section{Materials and methods}

Breast tissue and slides preparation for LCM. The normal breast tissue was obtained from a reduction mammoplasty from a postmenopausal woman after respective informed consent forms had been signed by the patient, according to the regulations of the Human Subjects Protection Committee. Fragments of breast tissue were fixed in ethanol $70 \%$ for $8 \mathrm{~h}$ at room temperature, and then were embedded in paraffin. Sections of $5 \mu \mathrm{m}$ were cut and stained with hematoxylin and eosin and then the laser capture microdissection (LCM) was performed.

Laser capture microdissection from breast tissue. The laser capture microdissection was performed using the PixCell II LCM system (Arcturus Engineering, Mountain View, CA). Fig. 1 shows the representative image of the epithelium and stroma cells before and after laser capture microdissection.

Determination of the number of cells captured from LCM. In order to investigate how many cells was extracted using LCM

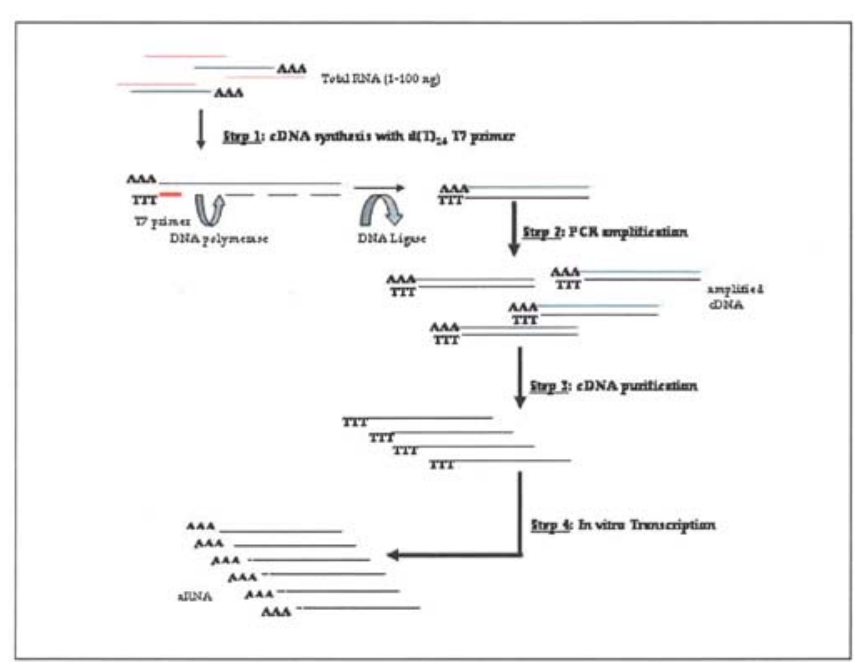

Figure 3. Diagram of PCR methodology.

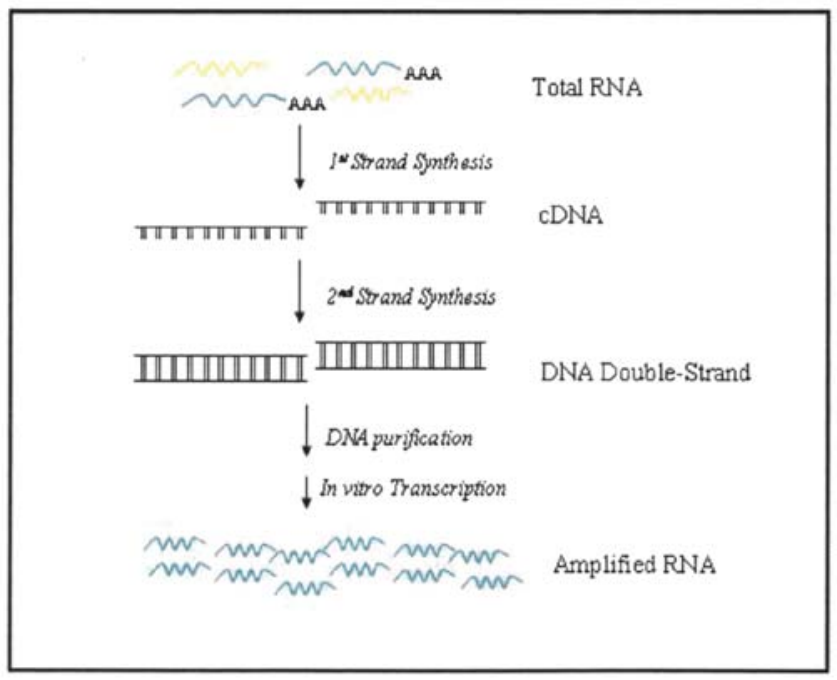

Figure 4. Diagram of linear methodology.

and how is the correlation between the number of the cells and the RNA isolated, we performed a curve using the pool of the RNA isolated in each patient and the number of the cells calculated using the following formula: Number of cells = $[(\mathrm{s} / \mathrm{t}) \times(\mathrm{m} / \mathrm{r}) \times(\mathrm{n})] \times \mathrm{N}$. In this formula, $\mathrm{s}=\mathrm{s}$ ize of the probe used for LCM (in $\mu \mathrm{m}) ; \mathrm{t}=$ size of the cells (in $\mu \mathrm{m}) ; \mathrm{m}=$ thickness of the cell captured $(\mu \mathrm{m}) ; \mathrm{r}=$ thickness of the cell $(\mu \mathrm{m}) ; \mathrm{n}=$ number of captures observed in the capsule after LCM; and $\mathrm{N}=$ number of the replicates. For example, if in the capsule 100 captures were observed, we used a $30-\mu \mathrm{m}$ probe size to perform LCM and if the size of the epithelial cells was $12 \mu \mathrm{m}$, the number of the cells would be $=[(30 \mu \mathrm{m} / 12 \mu \mathrm{m}) \mathrm{x}$ $(6 \mu \mathrm{m} / 12 \mu \mathrm{m}) \times 100] \times 3=375$ cells. Fig. 2 shows the curve of total RNA concentration isolated from LCM of breast epithelial cells and interlobular stromal cells versus the number of captured cells.

RNA isolation from LCM samples. From the LCM capsules, the RNA was isolated using TRIzol (Invitrogen, Inc.). The 
Table I. Description of the primers for cDNA amplification.

\begin{tabular}{lcc}
\hline Primers used & Description & Sequence \\
\hline Primer 1 & Oligo Dt-T7 primer & 5'-gca tta gcg gcc gcg aaa tta ata cga ctc act ata ggg aga ttt ttt ttt ttt ttt ttt ttt-3 \\
Primer 2 & Switch primer & 5'-aaa cga cgg cca gtg aat tgt aat acg act cac tat agg cgc ggg-3' \\
\hline
\end{tabular}

concentration and the quality of total isolated RNA were measured in the nanodrop (Nanodrop Technologies, Inc.) and in the Bioanalyzer (Agilent technologies). We used the RNA obtained from the laser capture microdissected epithelia and stroma of the normal breast for amplification using the PCR-RNA amplification developed in our laboratory (Fig. 3) and the established linear amplification method (Fig. 4).

The RNA was isolated by placing the LCM cap in a $50-\mu 1$ of TRIzol reagent. The cells were in contact with the reagent and placed on ice for $30 \mathrm{~min}$ (it can be stored overnight at $-20^{\circ} \mathrm{C}$ ). The following step was incubation at room temperature for $5 \mathrm{~min}$, followed by centrifugation for $15 \mathrm{~min}$ at 13,000 rpm at $4^{\circ} \mathrm{C}$, and addition of $20 \mu \mathrm{l}$ of chloroform for every $50 \mu \mathrm{l}$ of TRIzol. The mixture was added to PLGT Heavy Gel tubes, previously centrifuged for $2 \mathrm{~min}$ at $13,000 \mathrm{rpm}$, and centrifuged at $13,000 \mathrm{rpm}$ for $15 \mathrm{~min}$ at $4^{\circ} \mathrm{C}$. The aqueous phase was collected and $200 \mu \mathrm{l}$ of $100 \% \mathrm{EtOH}, 2 \mu \mathrm{l}$ of linear acrylamide, and $20 \mu \mathrm{l}$ of $\mathrm{AcNaOH}$ were added followed by incubation for $2 \mathrm{~h}$ at $-80^{\circ} \mathrm{C}$. At the end of the incubation, the sample was centrifuged at $13,000 \mathrm{rpm}$ at $4^{\circ} \mathrm{C}$ for $30 \mathrm{~min}$. The pellet was dried and washed with $200 \mu 1$ of $70 \% \mathrm{EtOH}$. After mixing, it was spun at $13,000 \mathrm{rpm}$ at $4^{\circ} \mathrm{C}$ for $15 \mathrm{~min}$. The pellet was dried by removing $\mathrm{EtOH}$ in vacufuge for 2-3 min. The pellet was dissolved in $11 \mu 1$ of DEPC water and measured in Nanodrop.

PCR-based RNA amplification procedure. The total RNA was amplified using a PCR method based on dT-T7-RNA amplification. The amplification procedure involves four steps (Fig. 3): 1) the cDNA synthesis using the RT enzyme (SuperScript from Invitrogen), 2) the amplification based on dT-T7 and switch T7 primers (Table I), 3) the in vitro transcription reaction and 4) the RNA purification and quantification. We performed two rounds of amplifications. We have used as reference a human universal reference RNA from Stratagene that was amplified identically to the sample under study. The RNA amplification procedures are described schematically in Fig. 3 and in detail below.

Step 1: reverse transcription. We started with $8 \mu 1$ of total RNA (100 ng) and added $1 \mu 1$ of oligo dT-T7 primer $(20 \mu \mathrm{m})$ (see sequence in Table I). We incubated the mixture at $70^{\circ} \mathrm{C}$ for $10 \mathrm{~min}$, chilled on ice, spun and added $4 \mu \mathrm{l}$ First Strand Buffer (5X), $2 \mu 1$ DTT (0.1 M), $2 \mu 1$ d'NTP mix (10X), $1 \mu 1$ Switch T7 primer $(20 \mu \mathrm{m})$ (see sequence in Table I), $1 \mu \mathrm{l}$ RNA $\sin (40 \mathrm{U} / \mu \mathrm{l})$. The reaction was incubated at $37^{\circ} \mathrm{C}$ for $1 \mathrm{~min}$ and then $1 \mu \mathrm{l}$ SuperScript II $(200 \mathrm{U} / \mu \mathrm{l})$ was added followed by incubation at $42^{\circ} \mathrm{C}$ for $1 \mathrm{~h}$ and addition of $1 \mu \mathrm{l}$ SuperScript II $(200 \mathrm{U} / \mu \mathrm{l})$. The reaction was incubated at $42^{\circ} \mathrm{C}$ for $1 \mathrm{~h}$ and at $95^{\circ} \mathrm{C}$ for $3 \mathrm{~min}$.
Step 2: cDNA amplification $(100 \mu \mathrm{l})$. Using $7.5 \mu \mathrm{l}$ of cDNA from Step 1, we added $2.0 \mu 1$ of dNTP mix (50X) (from Advantage 2 PCR kit BD Biosciences Clontech, Inc.), $4.0 \mu 1$ Oligo dT-T7 primer $(20 \mu \mathrm{m}), 4.0 \mu \mathrm{l}$ Switch T7 primer $(20 \mu \mathrm{m})$, 10.0 $\mu$ 1 PCR buffer (10X) (from Advantage 2 PCR kit BD Biosciences Clontech, Inc.), $2.0 \mu$ l Advantage 2 enzyme (50X) (BD Bioscences Clontech Cat no. K1910-Y) and $70.5 \mu 1$ of Water PCR grade. To this mixture we added $25 \mu 1$ of mineral oil and placed it in the termocycler under the following amplification program: $95^{\circ} \mathrm{C}(1 \mathrm{~min})$, Cycle I $(5$ cycles $), 95^{\circ} \mathrm{C}(30 \mathrm{sec}), 67^{\circ} \mathrm{C}(30 \mathrm{sec}), 72^{\circ} \mathrm{C}(6 \mathrm{~min})$. Cycle II (5 cycles) $95^{\circ} \mathrm{C}(30 \mathrm{sec}), 65^{\circ} \mathrm{C}(30 \mathrm{sec}), 72^{\circ} \mathrm{C}(6 \mathrm{~min})$. Cycle III (5 cycles) $95^{\circ} \mathrm{C}(30 \mathrm{sec}), 63^{\circ} \mathrm{C}(30 \mathrm{sec}) ; 72^{\circ} \mathrm{C}(6 \mathrm{~min})$. Cycle IV ( 5 cycles $) 95^{\circ} \mathrm{C}(30 \mathrm{sec}), 60^{\circ} \mathrm{C}(30 \mathrm{sec}), 72^{\circ} \mathrm{C}(6 \mathrm{~min}), 72^{\circ} \mathrm{C}$ ( $8 \mathrm{~min})$ and $4^{\circ} \mathrm{C}$ (hold). The cDNA was cleaned using the QIAquick PCR purification kit. For this purpose we added $500 \mu 1$ of binding buffer (Buffer PB from the QIAquick PCR purification kit) to the sample and placed the whole volume into the column. This step was followed by centrifugation for $15 \mathrm{sec}$ at $8,000 \mathrm{rpm}$. The flowthrough was discarded and $750 \mu 1$ of Buffer PE (from the QIAquick PCR purification kit) was added followed by centrifugation for $15 \mathrm{sec}$ at 8,000 rpm. The flowthrough was discarded and $500 \mu 1$ of Buffer PE (from the QIAquick PCR purification kit) was added followed by centrifugation for $1 \mathrm{~min}$ at $8,000 \mathrm{rpm}$. The flowthrough was discarded and the column was placed into a new Eppendorf tube followed by addition of $50 \mu 1$ of EB 1/10 (Elution buffer diluted 1/10 with PCR grade water) (from the QIAquick PCR purification kit) and incubation at room temperature for $1 \mathrm{~min}$. The mixture was centrifugated for $1 \mathrm{~min}$ at $8,000 \mathrm{rpm}$ and followed by addition of $50 \mu 1$ of EB 1/10 (Elution buffer diluted 1/10 with PCR grade water) and incubation at room temperature for $1 \mathrm{~min}$. The mixture was centrifuged for $1 \mathrm{~min}$ at $8,000 \mathrm{rpm}$ and dried in the vacuum machine at $30^{\circ} \mathrm{C}$ for $45 \mathrm{~min}$, until reaching an $8-\mu 1$ final volume.

Step 3: in vitro transcription (IVT) reaction. For the IVT reaction, we used reagents from the AmpliScribe T7 Transcription Kit from Epicentre Technologies (Cat no. AS3107). We started using the $8 \mu \mathrm{l}$ of purified PCR from Step 2 and added $4 \mu 1$ of AmpliScribe T7 Buffer (10X), $4 \mu 1$ of DTT (100 mM), $3 \mu 1$ of ATP $(100 \mathrm{mM}), 3 \mu 1$ of CTP $(100 \mathrm{mM})$, $3 \mu 1$ of UTP $(100 \mathrm{mM}), 3 \mu 1$ of GTP $(100 \mathrm{mM}), 1 \mu 1$ of RNase out, $1 \mu 1$ AmpliScribe T7 enzyme solution and $10 \mu 1$ PCR grade water. The mixture was incubated for $3 \mathrm{~h}$ at $37^{\circ} \mathrm{C}$, followed by another incubation for $1 \mathrm{~h}$ at $42^{\circ} \mathrm{C}$. To this reaction $1 \mu \mathrm{l}$ of DNAse (from AmpliScribe T7 Transcription Kit) was added and incubated for $15 \mathrm{~min}$ at $37^{\circ} \mathrm{C}$. 
Step 4: RNA purification and quantification. For the RNA purification we used the RNeasy mini kit from Qiagen cat no. 74104. To perform the RNA purification we followed the manufacturer's instructions and eluted twice with $50 \mu 1$ of PCR grade water. The quantification was performed employing $1 \mu \mathrm{l}$ of the purified RNA in the nanodrop (Nanodrop Technology). Ratio of 260/280 nm was used to evaluate the purity of the amplified RNA.

Linear amplification procedure. We employed a modification of the Eberwine amplification procedure (15) modified by Upson-Bellacosa (UB) (16) (Fig. 4). In this procedure a double-stranded cDNA (ds-cDNA) was synthesized from $1 \mu \mathrm{g}$ of total RNA using the SuperScript Double-Stranded cDNA Synthesis Custom Kit (Invitrogen, Carlsbad, CA), then mixed with $2 \mu \mathrm{l}$ of $20 \mu \mathrm{m}$ oligo-(dT)24-T7 primer [5'-AAACGAC GGCCAGTGAATTGTAATACGACTCACTATAGGCGC(dT)24-3'] in a total reaction volume of $11 \mu 1$ to initiate firststrand cDNA synthesis. The oligo-(dT)24-T7 primer and RNA were heat-denatured at $70^{\circ} \mathrm{C}$ for $10 \mathrm{~min}$, followed by annealing at $42^{\circ} \mathrm{C}$ for $2 \mathrm{~min}$. Four microliters of $5 \mathrm{X}$ first-strand reaction buffer (Invitrogen), $1 \mu 1$ of $10 \mathrm{mM}$ dNTPs, $2 \mu 1$ of $0.1 \mathrm{M}$ DTT, $0.8 \mu 1$ of T4gp32 $(5.0 \mathrm{mg} / \mathrm{ml})$ (USB), $1 \mu 1$ of RNasin (40 U/ $\mu 1$ ) (Promega, Madison, WI), and $1 \mu 1$ of SuperScript II $(200 \mathrm{U} / \mu \mathrm{l})$ were added to the reaction and incubated at $42^{\circ} \mathrm{C}$ for $2 \mathrm{~h}$. The reaction was heat-inactivated at $65^{\circ} \mathrm{C}$ for $15 \mathrm{~min}$ and chilled on ice for $5 \mathrm{~min}$. For secondstrand synthesis, $30 \mu 1$ of $5 \mathrm{X}$ second-strand reaction buffer, $3 \mu \mathrm{l}$ of $10 \mathrm{mM}$ dNTPs, $4 \mu \mathrm{l}$ of DNA Polymerase I (10 U/ $\mu \mathrm{l})$, $1 \mu \mathrm{l}$ of $E$. coli RNase $\mathrm{H}(2 \mathrm{U} / \mu \mathrm{l}), 1 \mu \mathrm{l}$ of $E$. coli DNA ligase ( $1 \mathrm{U} / \mu 1$ ), and $41 \mu \mathrm{l}$ of RNase-free water were added to the reaction and incubated at $16^{\circ} \mathrm{C}$ for $2 \mathrm{~h}$. Two microliters of T4 DNA Polymerase $(5 \mathrm{U} / \mu \mathrm{l})$ were added to the reaction and incubated at $16^{\circ} \mathrm{C}$ for an additional $15 \mathrm{~min}$. The reaction was heat-inactivated at $70^{\circ} \mathrm{C}$ for $10 \mathrm{~min}$. The resulting ds-cDNA was extracted with phenol/chloroform and then again with chloroform. The purified ds-cDNA was washed three times each with $500 \mu 1$ RNase-free water in Microcon YM-100 spin columns (Millipore, Bedford, MA), centrifuged at $500 \mathrm{~g}$ for $18 \mathrm{~min}$. The ds-cDNA was eluted and adjusted to a final volume of $9 \mu 1$ for amplification by T7 RNA Polymerase. The Ampliscribe T7 transcription kit (Epicentre Technologies, Madison, WI) was used for two consecutive rounds of in vitro RNA transcription. Nine microliters of the ds-cDNA, $2 \mu 1$ of $10 \mathrm{X}$ reaction buffer (Epicentre), $1 \mu 1$ each of $100 \mathrm{mM}$ ATP, GTP, CTP, and UTP, $2 \mu 1$ of $100 \mathrm{mM}$ DTT, $1 \mu \mathrm{l}$ of RNasin (40 U/ $\mu 1$ ) (Promega), and $2 \mu 1$ of T7 RNA Polymerase (Epicentre) were incubated at $37^{\circ} \mathrm{C}$ for $5 \mathrm{~h}$. The subsequent amplified, complementary RNA (aRNA) was extracted and a second round of RNA amplification was conducted, using the aRNA as a template to synthesize ds-cDNA. The resulting aRNA was extracted and adjusted to a final volume of $20 \mu 1$, the quality of aaRNA and the concentration was measured in the nanodrop and in the bioanalzyer (Agilent Technologies, CA).

Labeling and cDNA human microarrays. We have adopted the direct labeling of probes with amine-modified random primer using; $5 \mu \mathrm{g}$ of aaRNA as starting material. The $5 \mu \mathrm{g}$ of aaRNA $(8 \mu \mathrm{l})$ was combined with amine-modified random primer $(2 \mu \mathrm{g} / \mu \mathrm{l}, 1 \mu \mathrm{l})$ and RNase inhibitor $(5 \mathrm{U} / \mu 1,1 \mu \mathrm{l})$.
The mix was incubated at $70^{\circ} \mathrm{C}$ for $10 \mathrm{~min}$, and then chilled on ice for $10 \mathrm{~min}$. Primer-RNA solution was added to the reverse transcriptase mix (5X first-strand buffer, $6 \mu 1 ; 50 \mathrm{X}$ aa-dUTP/dNTPs (25 mM dATP, dGTP, and dCTP, $15 \mathrm{mM}$ dTTP, and $10 \mathrm{mM}$ aminoallyl-dUTP), $0.6 \mu \mathrm{l}$; DTT, $0.1 \mathrm{M}$, $3 \mu \mathrm{l}$; SuperScript II reverse transcriptase (Invitrogen/Life Technologies), $2 \mu \mathrm{l}$ ) and incubated at $42^{\circ} \mathrm{C}$ for $2 \mathrm{~h}$. The reaction was terminated by adding EDTA $(0.5 \mathrm{M}, 10 \mu \mathrm{l})$, and the RNA was hydrolyzed with $\mathrm{NaOH}(1 \mathrm{M}, 10 \mu \mathrm{l})$ at $65^{\circ} \mathrm{C}$ for $30 \mathrm{~min}$.

Probe purification. Probes were cleaned with a QIAquick PCR purification kit (Qiagen); the Cy3- and Cy5-labeled products were combined, followed by $500 \mu 1$ of Buffer PB. The samples were applied to QIA quick columns, which were centrifuged at $13,000 \mathrm{rpm}$ for $1 \mathrm{~min}$, after which the flowthrough were discarded. To wash the columns, $750 \mu 1$ of etanol $80 \%$ was added, columns were spun again for $1 \mathrm{~min}$, and the flowthrough were discarded. The washing step was repeated once more, and columns were spun again to remove residual ethanol. Fresh collection tubes were placed beneath each column, $40 \mu 1$ of PCR-grade water at $70^{\circ} \mathrm{C}$ was added, and tubes were incubated for $3 \mathrm{~min}$ at $70^{\circ} \mathrm{C}$. Columns were centrifuged at 13,000 rpm for $1 \mathrm{~min}$. Elutes were partially dried in a vacuum centrifuge and then resuspended in $15 \mu \mathrm{l}$ of hybridization buffer.

Hybridization and washing conditions. The Cy5-labeled probes $(15 \mu \mathrm{l})$ were combined with its corresponding human reference Cy3-labeled probes $(15 \mu 1)$. The probes were denatured at $98^{\circ} \mathrm{C}$ for $3 \mathrm{~min}$ and spun at 13,000 rpm for $3 \mathrm{~min}$ at room temperature. The products were pipetted onto arrays, coverslips were applied, and the slides were placed in a hybridization chamber (GeneMachines, from GeneMachines Company). Arrays were incubated in a water bath at $42^{\circ} \mathrm{C}$ for $16 \mathrm{~h}$, and subsequently washed with $0.5 \mathrm{X} \mathrm{SSC}, 0.01 \%$ (wt/vol) SDS, followed by $0.06 \mathrm{X} \mathrm{SSC}$, at room temperature for $10 \mathrm{~min}$ each. Slides were spun for $5 \mathrm{~min}$ at $800 \mathrm{rpm}$ (130 g) at room temperature.

Array scanning. Arrays were read with a Affymetrix 428 fluorescent scanner (MWG Technologies) at $10 \mu \mathrm{m}$ resolution and variable photomultiplier tube (PMT) voltage settings to obtain the maximal signal intensities with $<1 \%$ (wt/vol) probe saturation. The resulting images were analyzed using ImaGene version 4.2 and GeneSight version 4.0 (Biodiscovery, Inc., San Diego, CA) software.

Analysis. After Lowess normalization, the data were analyzed using GeneSigh 4.0 software (Biodiscovery, CA).

Quality control of amplified RNA by real-time RT-PCR. For real-time PCR (RT-PCR), the cDNA was synthesized for the control genes $18 \mathrm{~S}$, milk fat gene, whey acidic protein, inhibin alpha and beta gene using Taqman primer and probe set sequences. A ready to use primer and probe set pre-designed by Applied Biosystems (Assay-on demand Gene Expression Product from ABI) was used for the detection of the gene expression. All RT-PCR reactions were performed on the ABI PRISM 7000 Sequence Detection System (Applied 
Table II. RNA amplification by PCR and linear methodology.

\begin{tabular}{|c|c|c|c|c|c|c|c|}
\hline & \multicolumn{3}{|c|}{ BLR-PCR amplification method } & \multirow[b]{2}{*}{$\begin{array}{c}\text { aaRNA } \\
(\mathrm{ng} / \mu \mathrm{l})\end{array}$} & \multirow[b]{2}{*}{$\begin{array}{l}\text { aaRNA volume } \\
(\mu 1)\end{array}$} & \multirow[b]{2}{*}{ Ratio } & \multirow[b]{2}{*}{$\begin{array}{c}\text { Times of } \\
\text { amplification }\end{array}$} \\
\hline & $\begin{array}{l}\text { RNA } \\
(\mathrm{ng} / \mu \mathrm{l})\end{array}$ & $\begin{array}{l}\text { RNA volume } \\
\qquad(\mu 1)\end{array}$ & $\begin{array}{l}\text { aRNA } \\
(\mathrm{ng} / \mu \mathrm{l})\end{array}$ & & & & \\
\hline Epithelial cells & 4.30 & 10 & 2.360 & 498.2 & 100 & 2.00 & 1158 \\
\hline \multirow[t]{3}{*}{ Stroma cells } & 2.31 & 10 & 1.849 & 314.3 & 100 & 2.00 & 1359 \\
\hline & \multicolumn{3}{|c|}{ Linear amplification method } & & & & \\
\hline & $\begin{array}{c}\text { RNA } \\
(\mu \mathrm{g} / \mu \mathrm{l})\end{array}$ & $\begin{array}{l}\text { RNA volume } \\
\qquad(\mu 1)\end{array}$ & $\begin{array}{l}\text { aRNA } \\
(\mathrm{ng} / \mu \mathrm{l})\end{array}$ & $\begin{array}{c}\text { aaRNA } \\
(\mathrm{ng} / \mu \mathrm{l})\end{array}$ & $\begin{array}{c}\text { aaRNA volume } \\
(\mu 1)\end{array}$ & Ratio & $\begin{array}{c}\text { Times of } \\
\text { amplification }\end{array}$ \\
\hline Epithelial cells & 4.30 & 10 & 1.18 & 23.60 & 100 & 1.80 & 54 \\
\hline Stroma cells & 2.31 & 10 & 0.43 & 18.49 & 100 & 1.78 & 80 \\
\hline
\end{tabular}

Biosystems) using the fluorescent Taqman methodology (TaqMan One Step RT-PCR Master Mix Reagents, Applied Biosystems). The PCR cycle at which the fluorescence arises above the background signal is called the cycle threshold $\left(\mathrm{C}_{\mathrm{t}}\right)$. We used $100 \mathrm{ng}$ of amplified RNA for each RTPCR reaction in a total volume of $50 \mu 1$. Primer and probe concentration for the target gene were optimized according to the manufacturer's procedure. The thermal cycling conditions comprised $30 \mathrm{~min}$ at $48^{\circ} \mathrm{C}, 10 \mathrm{~min}$ at $95^{\circ} \mathrm{C}$ and 40 cycles of $15 \mathrm{sec}$ denaturalization at $95^{\circ} \mathrm{C}$ and $60 \mathrm{sec}$ annealing at $60^{\circ} \mathrm{C}$. The results were expressed as relative gene expression (RGE) using the $\Delta \mathrm{C}_{\mathrm{t}}$ method, as described by Livak and Schmittgen (28) and Benoy et al (29).

\section{Results and Discussion}

In the present work, we present evidence for optimal RNA isolation and amplification to perform genomic expression by cDNA microarray in laser captured microdissected epithelial and stroma cells of normal breast paraffin-embedded tissue. We have isolated epithelial and interlobular stroma cells from normal breast tissue (Fig. 1). Studying the captured cells we have established a formula that allows us to calculate the number of cells and the amount of RNA isolated from them. As we expected, the concentration of total RNA in the microcaptured epithelial cells was greater than the one obtained in the interlobular stroma cells (Fig. 2). This is explained by the fact that the number of nuclei in the interlobular stroma is significantly lower compared with the number of nuclei captured in the epithelial cells. The total RNA isolated was split in order to be amplified in parallel using both the PCR-based (Fig. 3) and the linear RNA amplification methodologies (Fig. 4).

Table II shows the concentration of the initial starting RNA, the concentration of the aRNA in $\mu \mathrm{g} / \mu \mathrm{l}$, the volume in $\mu 1$, the ratio 260/280 and the times of amplification of mRNA. The amplified RNA yield increased nearly 1,200-fold with 20 cycles in the PCR methodology after two rounds of amplification. As expected, the yield with the linear amplification procedure after two rounds of amplification was
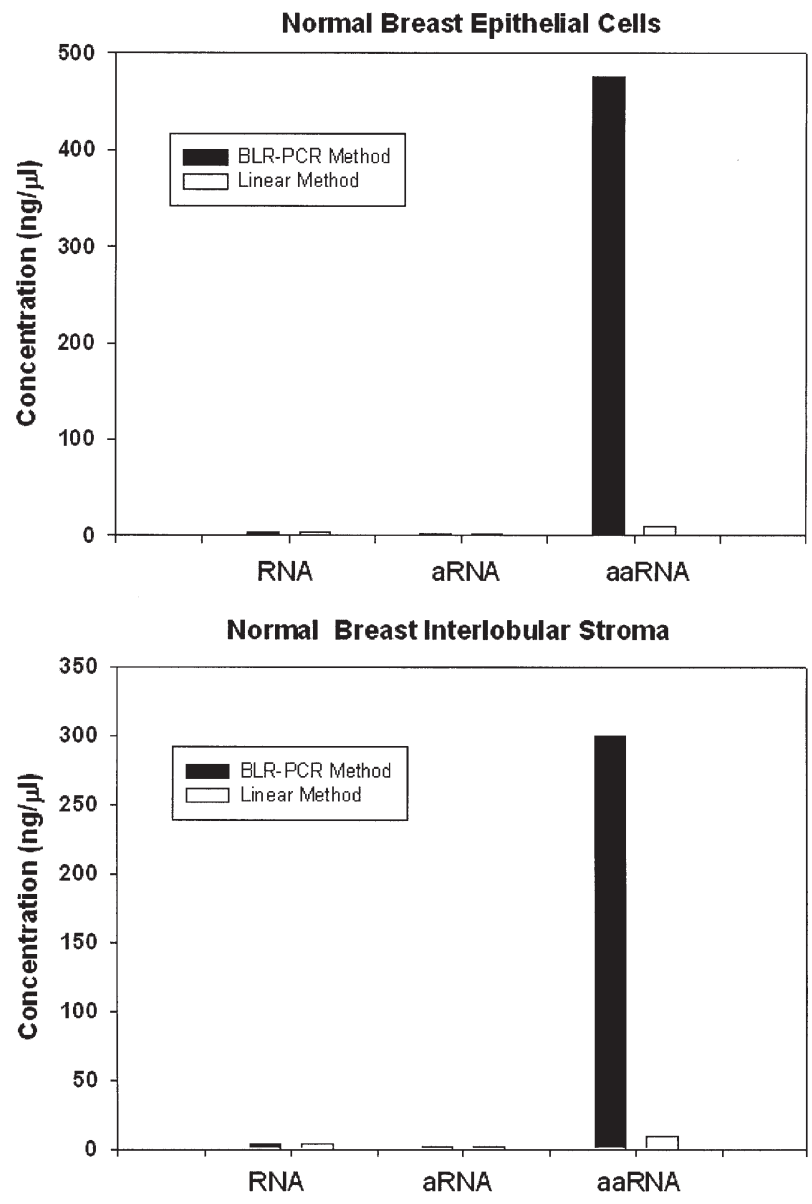

Figure 5. Normal breast epithelium and interlobular stroma RNA amplification of the breast epithelia and interlobular stroma using our methodology (BLR) and the linear amplification procedures.

significantly lower, 54- and 80-fold compared to the original RNA for the epithelia and stroma respectively (Table II and Fig. 5). The quality and the integrity of the amplified RNA using the PCR methodology was checked by the Bioanalyzer (Agilent Technologies) (Fig. 6). 

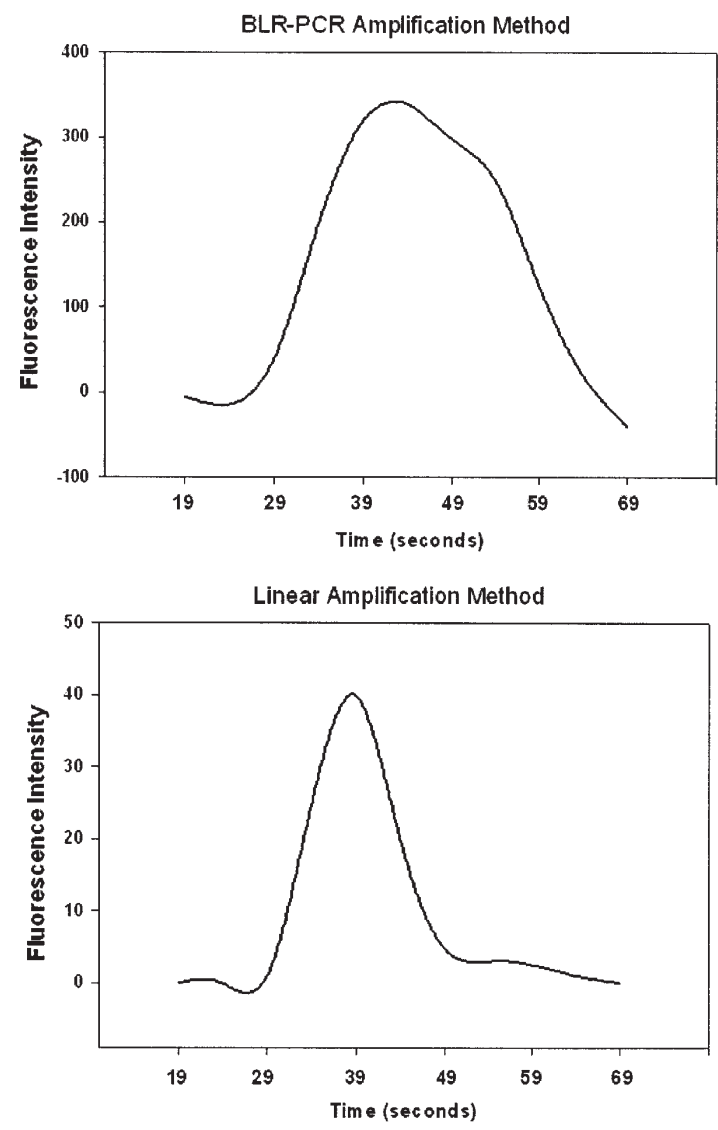

Figure 6. Electrophorogram of aaRNA quality using the Bioanalyzer (Agilent Biotechnologies). The Y represents the intensity of fluorescence (means quantity of total RNA) and X represents the time of elution in sec (means molecular weight of the RNA measured). The upper graphic represents the aaRNA of breast epithelial cells using the BLR-PCR method and the lower graphic represents the aaRNA of breast epithelial cells using the linear methodologies. In both cases the same starting amount of RNA was used.

The fluorescent probes were performed in triplicate and after checking the quality, the replicate from the same sample was combined and re-distributed into 3 separate tubes in order to have an identical replicate. Equal amount of fluorescent probe was used to hybridize to cDNA microarrays containing 15,000 genes, placing in the green channel (Cy3) the human universal reference RNA and in the red channel (Cy5) the amplified RNA samples. Fig. 7 represents the images of microarrays from epithelial (Fig. 7A) and stroma cells-LCM (Fig. 7B) from the two round-amplified RNA (aaRNA) using linear methodology (Fig. 7, right side) and from the aaRNA using PCR methodology (Fig. 7, left side).

We have performed the data analysis considering replicates; we combined the replicates from each condition such as aaRNA linear method and aaRNA by our PCR method. We employed the GeneSight software version 4.2 to analyze the gene expression profile. Typically, local background correction takes place spot by spot before replicate combination. GeneSight determines which values to combine by comparing the Gene IDs and combining all spots with the same ID. The combined replicate transformations also eliminate the outlier features compared with the other values for the same gene ID. For the remaining genes, the
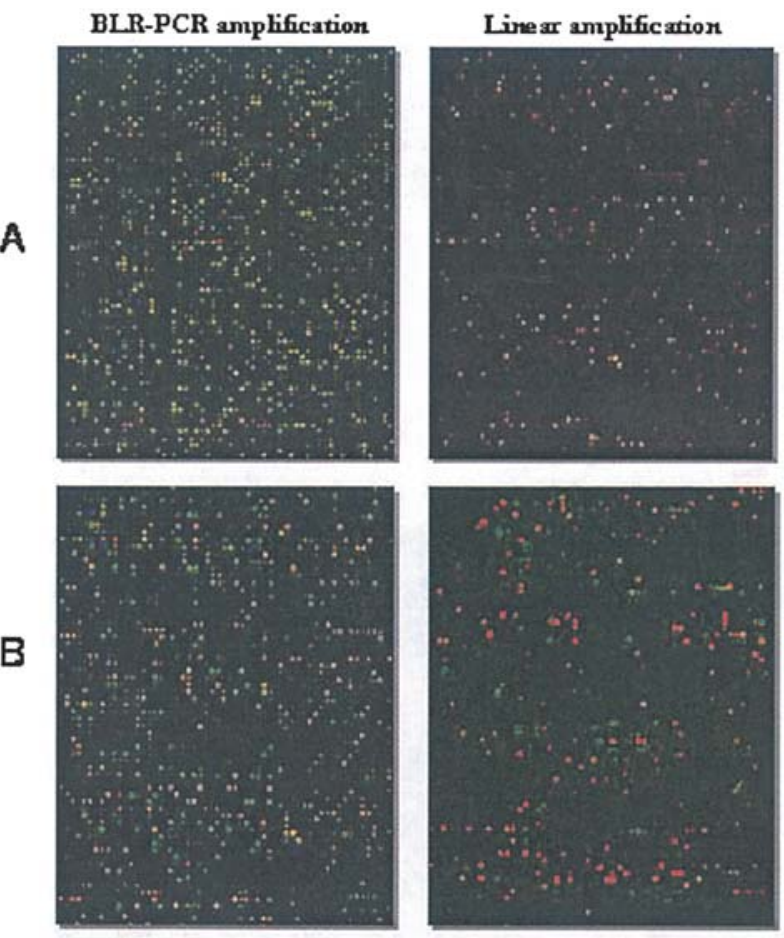

Figure 7. Normal breast epithelium and interlobular stroma cDNA microarray hybridization employing the aaRNA from BLR-PCR (left column) and linear amplification methodologies (light column). The A depicts the breast epithelium and row B the interlobular stroma.

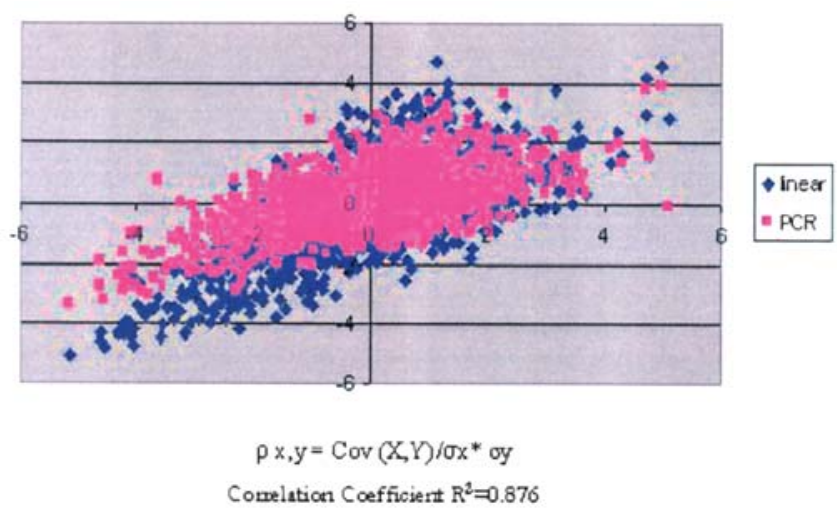

Figure 8. Correlation coefficient of gene expression analysis from linear and BLR-PCR amplification methodologies.

software computes the coefficient of variance, as a measure of confidence, which is available later for queries and the report. Lowess method was used to perform the data normalization, selecting a quadratic degree of fitness. We used a sub-grid normalization scope, omitting all the outliers and flagged spots from 1 to 7 . The scatter plot of Fig. 8 represents the gene expression of 12,565 genes out of 15,000 genes, showing a comparison between amplified RNA using linear methodology versus amplified RNA using PCR methodology. The correlation coefficient from both methodologies was 0.87 demonstrating that differences in gene expression for samples amplified using linear and PCR protocols are minor. 


\begin{tabular}{|c|c|c|c|c|}
\hline Initial Sources & $\begin{array}{l}\text { Bio analyzer Comparison } \\
\text { of Linear us } P C R\end{array}$ & $\begin{array}{l}\text { Microarray hybridization } \\
\text { [Linear Amplification } \\
\text { method). }\end{array}$ & $\begin{array}{l}\text { Microarray hybridization } \\
\text { (PCR Amplification } \\
\text { method). }\end{array}$ & $\begin{array}{l}\text { Correlation Coefficient } \\
\left.\mathbb{R}^{2}\right) \text { in the microarray } \\
\text { analysis Linear vs PaR } \\
\text { methods. }\end{array}$ \\
\hline Rat Mammary Cland & Lece & \%. & . & d] \\
\hline Mouse Liver & PCR & 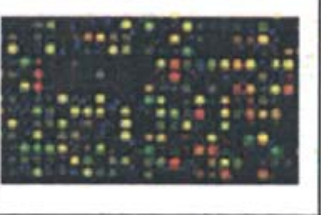 & 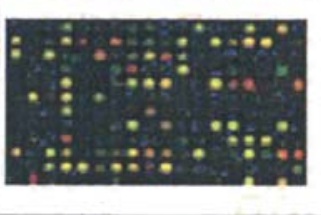 & $\underbrace{10.72}_{\text {max }}$ \\
\hline Human Breast & $\rightarrow \mathrm{RCR}$ & 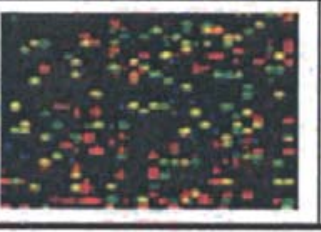 & 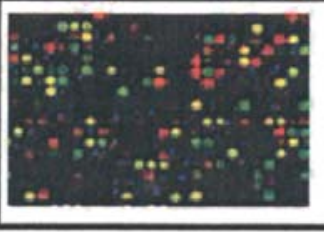 & 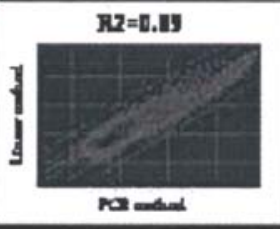 \\
\hline
\end{tabular}

Figure 9. Microarray hybridization using RNA obtained from linear and PCR amplification. The source of RNA was from rat mammary gland, mouse liver and human breast.

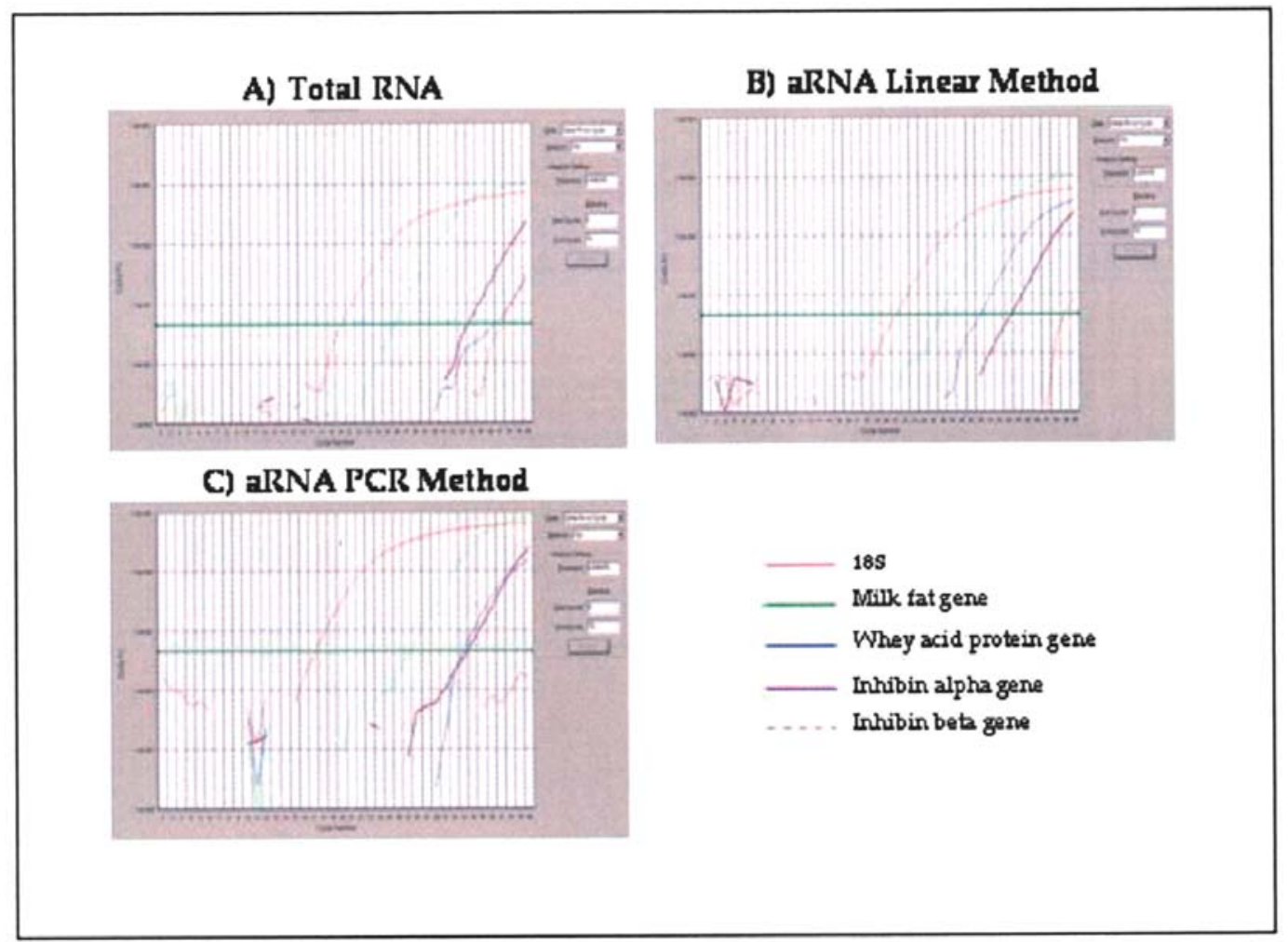

Figure 10. Real-time PCR amplification from total RNA, and amplified RNA using the linear and PCR methods.

We have further verified the correlation between both methods by processing frozen tissue of rat mammary gland, mouse liver and human breast tissue (Fig. 9). The quality of the amplified RNA using the PCR methodology was checked by the Bioanalyzer and in all the cases the amount of the aaRNA was higher using our PCR methodology than the linear one. We hybridized cDNA microarrays containing 15,000 genes, placing in the green channel (Cy3) the human universal reference RNA and in the red channel (Cy5) the RNA samples. The quality of the array was highly comparable and the scatter plots of gene expression comparison between amplified RNA using linear methodology versus amplified RNA using PCR methodology. The correlation coefficient from both methodologies was 0.87 for the rat mammary gland, 0.72 for the mouse liver and 0.89 for the human breast (Fig. 9). 
As another quality control we have validated by real-time PCR (RT-PCR), the genes 18S, milk fat, whey acid protein, inhibin alpha and beta genes using Taqman primer and probe set sequences, as indicated in Fig. 10. The data show that the relative gene expression was not significantly different between the total RNA versus the amplified RNA by both procedures.

Altogether, the present work demonstrated the proof of principle that paraffin sections of ethanol breast fixed tissue can be used for LCM and sufficient quality of amplified RNA for high-density cDNA microarray analysis can be produced. The data presented indicate that the quality and reproducibility of PCR RNA amplification procedures are quite comparable with the traditional linear methodology. We show that the correlation between the gene expression analysis from both methods is high - the amplification procedure maintains the gene expression profile of the original sample. Our PCR method of RNA amplification is fast, two rounds of amplification can be done in 3-4 days and is economical, because it needs less reagent compared to the linear amplification procedure. It is accurate, keeping intact the integrity of the original RNA and most importantly it gives a very high yield, enough to perform genomic studies from LCM samples from normal breast tissue.

\section{Acknowledgements}

This work was supported by Grant RO1-CA093599 from the National Cancer Institute, USA.

\section{References}

1. Tanner JM: The development of the reproductive system: In: Growth at Adolescence. Blackwell Scientific, Oxford, pp28-39, 1962.

2. Vorherr H: Development of the female breast: In: The Breast. Academic Press, New York, pp1-18, 1974.

3. Russo J and Russo IH: Development of human mammary gland. In: The Mammary Gland Development, Regulation, and Function. MC Neville and CW Daniel (eds). Plenum Publishing Corporation, New York, NY, pp67-93, 1987.

4. Russo IH and Russo J: Mammary gland neoplasia in long-term rodent studies. Environ Health Perspect 104: 938-967, 1996.

5. Jemal A, Murray T, Samuels A, Ghafoor A, Ward E and Thun MJ: Cancer Statistics, 2003. CA Cancer J Clin 53: 5-26, 2003.

6. Chu KC, Tarone RE and Brawley OW: Breast cancer trends of black women compared with white women. Arch Fam Med 8: 521-528, 1999.

7. MacMahon B, Cole P, Liu M, et al: Age at first birth and breast cancer risk. Bull World Health Organ 34: 209-221, 1970.

8. Russo J, Rivera R and Russo IH: Influence of age and parity on the development of the human breast. Breast Cancer Res Treat 23: 211-218, 1992.

9. Russo J, Romero AL and Russo IH: Architectural pattern of the normal and cancerous breast under the influence of parity. $\mathrm{J}$ Cancer Epidemiol Biomarkers Prev 3: 219-224, 1994.

10. Russo J and Russo IH: Development of the human breast: In: Encyclopedia of Reproduction. Vol. 3. Knobil E and Neill JD (eds.) Academic Press, New York, pp71-80, 1998.

11. Zhuang Z, Bertheau P, Emmert-Buck MR, et al: A microdissection technique for archival DNA analysis of specific cell populations in lesions <1 mm in size. Am J Pathol 146: 620$625,1995$.
12. Shibata D, Hawes D, Li ZH, Hernandez AM, Spruck CH and Nichols PW: Specific genetic analysis of microscopic tissue after selective ultraviolet radiation fractionation and the polymerase chain reaction. Am J Pathol 141: 539-543, 1992.

13. Whetsell L, Maw G, Nadon N, Ringer D and Schaefer FVL: Polymerase chain reaction microanalysis of tumors from stained histological slides. Oncogene 7: 2355-2362, 1992.

14. Kuppers R, Rajewsky K, Zhao M, et al: Hodgkin disease: Hodgkin and Reed-Sternberg cells picked from histological sections show clonal immunoglobulin gene rearrangements and appear to be derived from B cells at various stages of development. Proc Natl Acad Sci USA 91: 10962-10966, 1994.

15. Bonner RF, Emmert-Buck M, Cole K, et al: Laser capture microdissection: molecular analysis of tissue. Science 278: 1482-1483, 1997.

16. Emmert-Buck MR, Bonner RF, Smith P, et al: Laser capture microdissection. Science 274: 998-1001, 1996.

17. Schuetz CS, Bonin M, Clare SE, et al: Progression-specific genes identified by expression profiling of matched ductal carcinomas in situ and invasive breast tumors, combining laser capture microdissection and oligonucleotide microarray analysis. Cancer Res 66: 5278-5286, 2006.

18. Yang F, Foekens JA, Yu J, et al: Laser microdissection and microarray analysis of breast tumors reveal ER-alpha related genes and pathways. Oncogene 25: 1413-1419, 2006

19. Nishidate T, Katagiri T, Lin ML, et al: Genome-wide geneexpression profiles of breast-cancer cells purified with laser microbeam microdissection: identification of genes associated with progression and metastasis. Int J Oncol 25: 797-819, 2004

20. Sgroi DC, Teng S, Robinson G, Le Vangie R, Hudson JR Jr and Elkahloun AG: In vivo gene expression profile analysis of human breast cancer progression. Cancer Res 59: 5656-5661, 1999.

21. Luzzi V, Mahadevappa M, Raja R, Warrington JA and Watson MA: Accurate and reproducible gene expression profiles from laser capture microdissection, transcript amplification, and high density oligonucleotide microarray analysis. J Mol Diagn 5: 9-14, 2003.

22. King C, Guo N, Frampton GM, Gerry NP, Lenburg ME and Rosenberg CL: Reliability and reproducibility of gene expression measurements using amplified RNA from lasermicrodissected primary breast tissue with oligonucleotide arrays. J Mol Diagn 7: 57-64, 2005.

23. Luzzi V, Holtschlag V and Watson MA: Expression profiling of ductal carcinoma in situ by laser capture microdissection and high-density oligonucleotide arrays. Am J Pathol 158: 2005-2010, 2001.

24. Balogh GA, Heulings R, Mailo DA, Russo PA, Sheriff F, Russo IH, Moral R and Russo J: Genomic signature induced by pregnancy in the human breast. Int J Oncol 28: 399-410, 2006.

25. Eberwine J, Yeh H, Miyashiro K, Cao Y, Nair S, Finnell R, Zettel $\mathrm{M}$ and Coleman P: Analysis of gene expression in single live neurons. Proc Natl Acad Sci USA 89: 3010-3014, 1992.

26. Phillips J and Eberwine JH: Antisense RNA amplification: a linear amplification method for analyzing the mRNA population from single living cells. Methods 10: 283-288, 1996.

27. Upson JJ, Stoyanova R, Cooper HS, et al: Optimized procedures for microarray analysis of histological specimens processed by laser capture microdissection. J Cell Physiol 201: 366-373, 2004.

28. Livak KJ and Schmittgen TD: Analysis of relative gene expression data using real-time quantitative PCR and the 2(-Delta Delta C(T)) Method. Methods 25: 402-408, 2001.

29. Benoy IH, Elst H, van der Auwera I, et al: Real-time RT-PCR correlates with immunocytochemistry for the detection of disseminated epithelial cells in bone marrow aspirates of patients with breast cancer. Br J Cancer 91: 1813-1820, 2004. 